\title{
Regulation of the flow in the area of the damless water intake
}

\author{
Dilshod Bazarov, Bekhzod Norkulov, Oybek Vokhidov ${ }^{1 *}$, Fotima Artikbekova, Bobur \\ Shodiev, and Ikboloy Raimova \\ Tashkent Institute of Irrigation and Agricultural Mechanization Engineers, Tashkent, Uzbekistan
}

\begin{abstract}
The article discusses the results of numerical studies of the flow of the Amudarya river above the point of the damless water intake to the head structure of the damless water intake to the Karshi Main Canal-KMC. The system of two-dimensional equations of hydrodynamics-Saint-Venant is used as the basis of the mathematical model. In this work, a series of calculations of the field of currents in the river channel during low-water periods is carried out. Below are the main research results and proposals for ensuring the stable operation of the damless water intake in low-water conditions. The applicability of a numerical model composed of the equations of shallow water - the vector equation for the conservation of momentum and the scalar equation for the conservation of mass, has been proved, when describing a flow with the presence of circulation zones, which is typical when the water flow is constrained by blind dams. In this case, the solution pulsates around a certain average value, and the average length of the circulation zone behind the sudden expansion of the open flow is in good agreement with laboratory experiments. Numerical studies have shown that the device of a jet-guiding dam $150 \mathrm{~m}$ above the water intake gate in the CMC is more effective than when the dam is located 250 $\mathrm{m}$ above. In essence, dam № 2 with a length of $65 \mathrm{~m}$ does not affect the conditions at the water intake in the KMC at all, and dam № 2 with a length of $120 \mathrm{~m}$ is almost equivalent in its impact on the flow to dam №1 with a length of $50 \mathrm{~m}$. Analysis of the results shows that the placement of an additional threshold in the Amudarya river bed improves the situation by raising the water level at the water intake. The threshold is flooded even at low water levels, which reduces the speed load on its body. At the same time, the threshold is located directly at the beginning of the channel, in part to protect the intake from incoming sediment, and high enough speed water glistening over the threshold in line, ensure the transit of sediment that can reduce enters the intake. Such measures will reduce the turbidity of water entering the channel. This, in turn, reduces the intensity of the silting process.
\end{abstract}

"Corresponding author: vohidov.oybek@bk.ru 


\section{Introduction}

An increase in the degree of regulation of the river in its upper course significantly affects the mode of operation of the head structures of damless water intakes located downstream. This fact is often accompanied by the emergence of significant difficulties in the operation of the head structures of damless water intakes. To ensure a guaranteed water intake in the head structures, it is necessary to perform a complex of engineering works with scientifically based methods. These categories of head structures include the head structure of the damless water intake into the Karshi Main Canal-KMC, which is considered as the object of research of this work. The head structure of the KMC takes water from the Amudarya by a damless method. Due to the increased degree of regulation of the upper course of the Amudarya River, the hydrological regime of the river changes dramatically, where a decrease in flow is characteristic of this change. This is in turn .complicates the guaranteed flow of water into irrigation channels. This factor is especially pronounced when water is taken to the head structure of the damless water intake in the KMC. To ensure a guaranteed volume of water in the head structure, it is necessary to direct the flow of water towards the right bank. To do this, it is necessary to conduct scientific research to identify the features of the hydraulic regime of the river and its dynamics under the influence of water extraction into the main structure of the damless water intake, which will justify the relevance of this work.

The Amudarya River is the largest river in Central Asia. Its length from the sources of the Panj River is $2540 \mathrm{~km}$, the catchment area is 309 thousand $\mathrm{km} 2$ (excluding the catchment area of the Zeravshan River). The river is snow-fed and glaciated. The average annual flow rate is $1350-1720 \mathrm{~m} 3 / \mathrm{s}$, the average flow rate is $370 \mathrm{~m} 3 / \mathrm{s}$ [1]. The flow of the Amudarya River is characterized by significant intra-annual and multi-year unevenness, and in a low-water year (90\% availability) it is more than $20 \mathrm{~km} 3$ less than in a year of average water content [13]. At the same time, the maximum flow rate of up to $6000 \mathrm{~m} 3 / \mathrm{s}$ can be observed in the summer, and the minimum-in January-February. Fluctuations in the water level can reach 2.5-3.0 $\mathrm{m}$ [12].

The Amudarya River is also characterized by the fact that it flows in extremely easily eroded soils. The instability of the Amudarya riverbed, due to constant erosion and the build-up of banks, creates exceptional difficulties for the stable operation of water intake facilities, as a result of which there are significant fluctuations in water flow, including in the supply channels.

One of these water intake structures is the damless water intake to the Karshi Main Canal (KMC), located in the middle reaches of the Amudarya River. This object of research is located in the vicinity of the settlement of Kyzylayak, the Republic of Turkmenistan.It carries out water supply through the cascade of pumping stations of the Karshi Main Canal with 19 lifts to the irrigated areas of the Kashkadara viloyat of the Republic of Uzbekistan. The volume of water taken in is $180 \mathrm{~m} 3 / \mathrm{sec}$.

It is intended for irrigation of 402 thousand hectares of land, including 392 thousand hectares in Uzbekistan and 10 thousand hectares in Turkmenistan. The water intake from the Amudarya river to the canal is located on the territory of Turkmenistan, approximately $20 \mathrm{~km}$ upstream from the Kerki gauging station, on the right bank of the river in the area of Cape Pulizindan, formed by rock formations. It should be noted that the choice of the location of the water intake was caused precisely by the fact that in this place the right bank is stable due to the presence of rocky unbreakable rocks of Cape Pulizindan.

In the area of the water intake of the Amudarya River is characterized by an exceptionally high transporting capacity (up to $5 \mathrm{~kg} / \mathrm{m} 3$, [3]). Here p. The Amudarya has a wide floodplain. The stream shaft often changes its location on it and moves either closer to the right bank or to the left. On the right bank, islands or a stable sandbank are formed, 
moving downstream from Cape Pulizindan in the form of a spit, which are flooded during the flood period.

The channel in the area of the water intake wanders, deviating in high-water years to the right, and in low-water - to the left bank. The channel, regulating and bank protection structures in the area adjacent to the water intake are practically absent. The water intake and the throughput of the head section of the canal are supported by the year-round operation of dredgers.

On the $78.4 \mathrm{~km} \mathrm{KMC} \mathrm{section,} \mathrm{there} \mathrm{are} 6$ pumping stations that raise water to a total height of $132.2 \mathrm{~m}$. At the end of this section there is the Talimarjan reservoir with a usable capacity of 1400 million $\mathrm{m} 3$, which carries out seasonal flow regulation.

Since the water intake at the KMC is not equipped with engineering structures and, in fact, is a ditch from the river, connecting the river with the first pumping station, all sediment from the river flows directly into the canal. This situation leads to negative consequences, including the siltation of not only the inlet part, but also other parts of the canal, up to the Talimarjan reservoir.

To carry out this work, it is necessary to study a two-dimensional flow in open channels. The most convenient, cheap and multivariate is the method of numerical research $[1,2,4,8-11]$. A detailed comparison of the results of numerical and laboratory modeling of the flow in open channels with a sharp increase in the channel width characteristic of the movement of a water flow behind blind dams was carried out in [16-20].

In earlier works, it was noted that when numerical modeling of flows in such channels using full hydrodynamic equations of water flow motion, taking into account the convective terms, a whirlpool zone appears behind the ledge, which is observed both in physical experiments and in natural conditions; if we use simplified equations with discarded convective terms, the flow spreads immediately behind the ledge, without forming a whirlpool [4]. Note that this paper does not note the impossibility of realizing the hydraulic phenomena described by the Saint-Venant equations without taking into account the friction between the jets in terms of the stationary whirlpool zone corresponding to the Kartvelishvili theorem [5].

In [7], which compared a large number of results of numerical and laboratory experiments by various authors (including the results of her own experiments), at sufficiently large flow depths, the relationship between the relative length of the whirlpool zone $l_{b} / b$ and the parameter $\lambda b / h$ it is violated even for very small values of the Froude number. The author explains this violation by the need to take into account the forces of turbulent viscosity in this case in the mathematical model. Note, however, another factor that can affect the length of the whirlpool: the presence of pulsations (input turbulence) in the entrance gate.

In the numerical experiments [6], there were no pulsations of hydrodynamic values in the entrance gate. According to the results of our studies, at low water depths in the inlet prismatic section of the channel, the input pulsations are attenuated, and at high flow depths they do not attenuate. A detailed study of the applicability of the planned Saint-Venant equations for sharply unsteady flows in zones of significant changes in the shape of the channel is carried out in [9]. We considered a channel of rectangular cross-section without a bottom slope with a sharp five-fold expansion in the plan. A quick-opening shutter was installed in the expansion flap. Before opening the gate on a narrow section of the channel, the depth exceeded the depth on a wide section. When the gate was opened, a breakthrough wave occurred; during the period of its propagation in the region, measurements of the hydrodynamic parameters of the flow were carried out. The authors of this paper [11] investigated the effect of the length step on the results of numerical experiments. Based on the results of numerical studies, graphs of the time change in the longitudinal component of the velocity following a sudden twofold expansion of the channel are presented. These 
graphs and the results presented above clearly demonstrated the behavior of the water velocity in the area below the sudden expansion. The current was always non-stationary and had the character of stationary pulsations, and the smaller the grid, the richer the spectrum of these pulsations. The time step in the calculations has always been much less than the minimum ripple period, so these ripples are not related to the difference oscillations that can occur when approximated by central differences. Since the flow is strongly elongated along the longitudinal direction, a large ratio of steps was chosen for the main series of calculations. According to the authors of the above studies and this article together show that the pulsations on different grids differ significantly, the average values of the velocities are close, i.e. the solution for the average values converges well, and it is proved that the pulsations are a property of the original Saint-Venant equations.

Despite the abundance of works devoted to the two-dimensional flow movement, the flow movement in a curved channel under conditions of water withdrawal is not sufficiently studied. Therefore, the numerical study of two-dimensional flow motion on a curved section is defined as the main goal of this work. Based on the above goal, the research objectives are formulated:

- Selection of a system of two-dimensional hydrodynamic equations describing the flow motion in open channels;

- Carrying out numerical studies of the flow movement on a curved section of the river in the area of the head structure of the damless water intake on its basis;

- Conducting several variants of numerical research with spurs of different lengths and locations and selecting their optimal location in order to ensure optimal water intake into the head structure of a damless water intake.

\section{Method}

Conducting numerical studies using a mathematical model adapted to a real object and based on the results obtained, developing recommendations for improving the operating conditions of the object of research is the method of research of this work.

\section{Results and Discussion}

On the $78.4 \mathrm{~km}$ section of the KMC, there are 6 pumping stations that lift water to a total height of $132.2 \mathrm{~m}$. At the end of this section is the Talimarjan liquid reservoir with a useful capacity of 1400 million $\mathrm{m} 3$, which performs seasonal flow control.

To date, there are practically no effective algorithms for solving three-dimensional problems in a complete formulation. However, in [6] it is shown that when introducing the scale of consideration:

$$
M_{L}=L_{n}^{2} T
$$

where $L_{n}$ - linear scale in the plan (with, $L_{n}>>h$, where $h$ - the depth of the flow); $T=L_{n} / U$, where $U$ - the characteristic velocity of the flow, and provided that general equations of hydrodynamics [7]:

$$
\frac{\rho_{\max }-\rho_{\min }}{\rho_{\max }+\rho_{\min }}<<1
$$




$$
\begin{aligned}
& \frac{\partial u_{i} \rho}{\partial t}+\frac{\partial u_{i} u_{j} \rho}{\partial x_{j}}+\frac{\partial \rho}{\partial x_{i}}=\frac{\partial \tau_{i j}}{\partial x_{j}}+g_{i} \rho \\
& \frac{\partial \rho}{\partial t}+\frac{\partial u_{i} \rho}{\partial x_{i}}=0 ; \quad \frac{\partial S_{r}}{\partial t}+\frac{\partial S_{r} u_{j}}{\partial x_{j}}=q_{S r} \\
& \rho=f\left(S_{r}\right) ; \quad i=1,2,3,
\end{aligned}
$$

where $u_{i}$ - projection of the current velocity vector on the axis $x_{i}, p$ - hydrodynamic pressure, $\tau_{i}$ - component of the physical tangential stress tensor, $\rho$ - density, $g_{i}$ - component of the gravity acceleration vector, $q_{S r}$ - internal sources of substance for a Newtonian fluid, $v$ - kinematic viscosity of the liquid, $S_{r}$ - some substance that determines the density (temperature, salinity) and

$$
\tau_{i j}=\left(\frac{\partial u_{i}}{\partial x_{j}}+\frac{\partial u_{j}}{\partial x_{i}}\right) v \rho
$$

we can lead to the following system of equations:

$$
\left\{\begin{array}{l}
\frac{\partial u_{i}}{\partial t}+\frac{\partial u_{i} u_{j}}{\partial x_{j}}+\frac{\partial u_{i} w}{\partial z}+g\left(\frac{\partial z_{\Gamma}}{\partial x_{i}}+\frac{1}{\rho} \int_{z}^{z_{\Gamma}} \frac{\partial \rho}{\partial x_{i}} \partial z\right)=\frac{\partial}{\partial z} v_{T} \frac{\partial u_{i}}{\partial z}+\frac{\partial}{\partial z} \mu \frac{\partial u_{i}}{\partial z} \frac{1}{\rho} \\
\frac{\partial u_{i}}{\partial x_{i}}+\frac{\partial w}{\partial z}=0 \\
\frac{\partial S_{r}}{\partial t}+\frac{\partial S_{r} u_{j}}{\partial x_{j}}+\frac{\partial S_{r} w}{\partial z}=\frac{\partial}{\partial z} D \frac{\partial S_{r}}{\partial z}+q_{S z} \\
\rho=\rho\left(S_{r}\right)
\end{array}\right.
$$

where $D$ - the coefficient of vertical diffusion (analogue $v_{T}$ - coefficient of turbulent viscosity), it is usually assumed, what $D=\alpha v_{T}, S_{r}$ - average concentration of the substance on the scale (1).

The same equations can be obtained from the Reynolds equations with the additional assumption that it is possible to neglect the turbulent interactions between the liquid jets in the plan. Also, two different approaches lead to the same equations. However, from the point of view of the expected results of these approaches are not equivalent. Indeed, note that all dependent variables are $u_{i}, q_{i}$ and $h$ In (5), they have different meanings depending on whether these equations are derived from the Reynolds equations or directly from the conservation laws. In the first case, these values are averaged first by probability and then by a large scale, in the second case, these are actual values averaged by the same scale.

The system of equations (5) is derived from the laws of conservation of momentum and mass without any specific assumptions about the rheology of the fluid. To close the system of equations, it is sufficient to specify the relationship between the tangential stresses at the bottom ( $\tau$ i) and the rest of the flow characteristics. It is generally assumed that this relationship can be expressed by the relation

$$
\tau_{i}=\lambda U_{i}|U| / 2
$$

where $\lambda$ - scalar coefficient of hydraulic friction, which is calculated by the Manning formula: 


$$
\lambda=\frac{2 g}{C^{2}}=\frac{2 g n^{2}}{h^{1 / 3}}
$$

where $C$ - Shezi coefficient, $n$ - the coefficient of roughness.

All of the above is also true for a flow that is free of boundaries in terms of flow. If the flow is considered near a rough vertical wall, then since $\tau_{c}$ and $\tau_{b}$ they are determined by the roughness of the walls and the bottom, respectively, and the assumption that all the characteristics change slightly along the horizontal coordinate compared to the change along the vertical one leads to the fact that, in the first approximation, in the expansion by a small parameter $\alpha=L / h$, leads to hydrostatic pressure at a given scale, also

$$
\frac{\partial P}{\partial z}=g \bar{\rho}
$$

Moving on to the roughness coefficients (7) can be written as:

$$
\frac{L_{n}}{h}>\left(\frac{n_{c}}{n_{b}}\right)^{2}
$$

Expression (8) is one of the main limitations imposed on the scope of the Saint-Venant equations.

The conditions for the application of equations (5), including the setting of boundary conditions, are well described in [14-17].

In this paper, the two-dimensional Saint-Venant equations were numerically implemented using the explicit finite-difference scheme of A. N. Militeev [14]. Hydraulic numerical experiments to study the flow regime in the river bed were carried out by the establishment, i.e. asked some initial water level in the current fragment, the flow of water at the entrance to this piece, water consumption, selected channel and curve when the flow rate and the water level at the output of the calculated fragment. After that, calculations were carried out until the time when the mode is established and the sum of the flow taken into the channel and the flow at the exit from the area becomes equal to the flow of water at the entrance.

Using the created mathematical model of the area near the water intake in the KMC and the use of adapted software, a series of calculations was carried out to study the possible improvement of water intake conditions in the low-water period by installing jet-guiding dams and semi-dams directly next to the entrance to the channel, including in order to increase the water level at the water intake.

The low-water period is the most difficult to operate, since water intake during this period is difficult. In this paper, a series of calculations of the flow field in the Amudarya River in the low-water period with water flow rates $Q=500 \mathrm{~m} 3 / \mathrm{s} 5$ and $300 \mathrm{~m} 3 / \mathrm{s}$ and (with flow rates taken into the channel of $100 \mathrm{~m} 3 / \mathrm{s}$ and $30 \mathrm{~m} 3 / \mathrm{s}$, respectively) is carried out.

Since the section of the calculated fragment from the water intake in the CMC to the exit gate is small, the connection curve $Z=F(Q)$ presented in [16] was set as the boundary condition at the exit from the calculated fragment.

As a basis for numerical modeling, several computational grids were defined and constructed. Based on the available topographic data, the initial calculations of the current field in this zone were carried out on a finite-difference grid with a step along the current $\Delta X=36.8 \mathrm{~m}$ (with the exception of 4 lines at the entrance section, in which the step $\Delta X$ was $22 \mathrm{~m}, 24 \mathrm{~m}, 28 \mathrm{~m}$ and $33 \mathrm{~m}$ ) and across the current $\Delta Y=20 \mathrm{~m}$. The boundary of the calculated area upstream of the water intake was located at a distance of about $3 \mathrm{~km}$, and the lower one at a distance of about $2 \mathrm{~km}$ below the water intake (Fig. 1). 


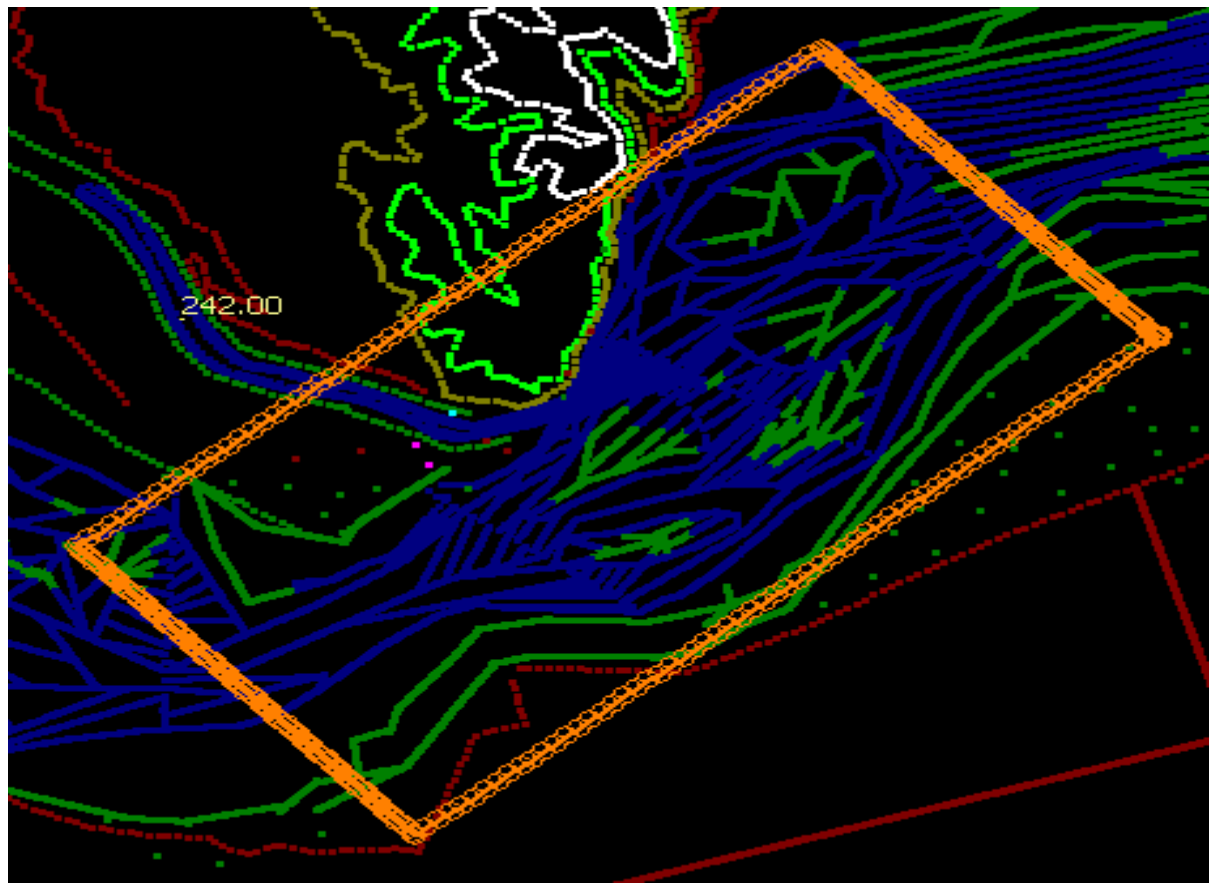

Fig. 1. Marking of a uniform grid

In addition, it built a grid that clumps the size of $8.200 \mathrm{~m}$ to $4.200 \mathrm{~m}$ (Fig. 2). Steps in length in this case amounted to $209 \mathrm{~m}$, and the width varied from $190 \mathrm{~m}$ at the entrance and exit of the computational domain to $37.5 \mathrm{~m}$ near the head of the intake, as well as grid covering the area of interest modeling in the area of water intake KMC smaller steps $\Delta X=15 \mathrm{~m}, \Delta Y=10 \mathrm{~m}$.



Fig. 2. Grid layout with thickenings 
In order to study the details of the flows directly in the water intake area, a fine uniform finite-difference grid with steps $\Delta \mathrm{X}=15 \mathrm{~m} \Delta \mathrm{Y}=20 \mathrm{~m}$ was used. In some cases, the detail of the results obtained using this finite-difference grid was also insufficient, and an uneven grid with steps was constructed in the area near the water intake $\Delta \mathrm{X}=7.5 \mathrm{~m} \Delta \mathrm{Y}=10 \mathrm{~m}$.

At a distance from the water intake in the KMC, outside the area of the uniform grid with such steps, the steps on the grid $\Delta \mathrm{X}$ and $\Delta \mathrm{Y}$ increase by $10 \%$. At the same time, for an uneven grid, updated topographic information was not used; the bottom marks in the cells of the uneven grid were assumed to be equal to the bottom marks in the cells of the uniform grid, in which the centers of the cells of the uneven grid fell. Of course, with this method of determining the bottom marks within the thickening area near the water intake in the KMC, each cell of the original uniform grid was divided into 4 cells, and in all these 4 cells, the bottom mark was equal to the mark in the corresponding cell of the original uniform grid.

As shown by the performed numerical experiments, it is impossible to ensure the supply of the required water flow to the $\mathrm{CMC}$ without engineering measures. Of course, the insufficiently accurate initial data do not give the right to say unequivocally that the coincidence of difficulties in real practice with the results of the calculation is not accidental. However, this fact at least confirms the need for more research.

Figure 3 shows the result of the experiment when passing the measured flow rate without additional engineering measures on a uniform grid.

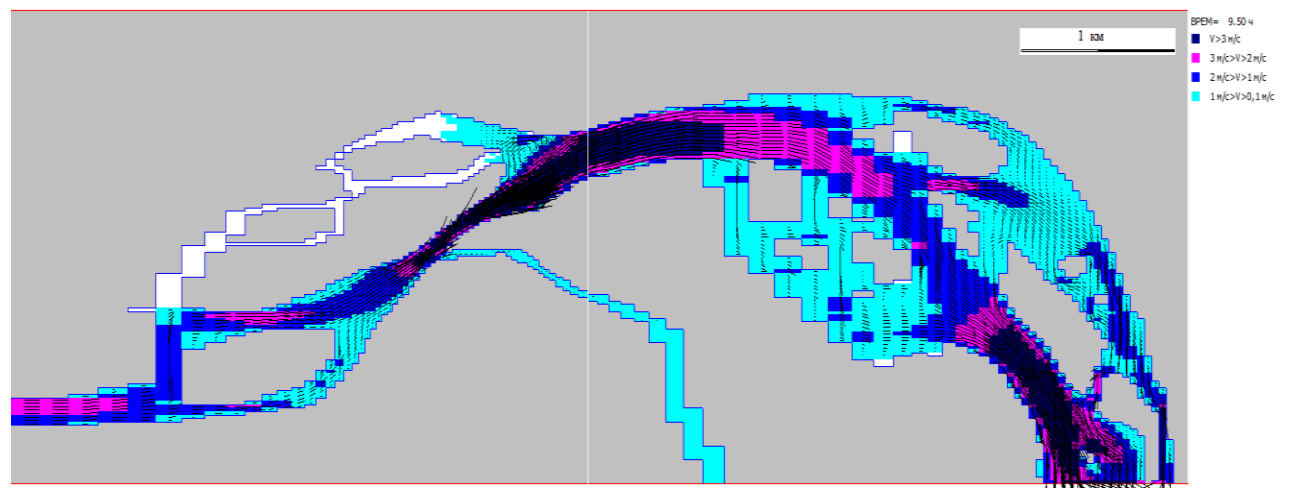

Fig. 3. Numerical experiment with the passage of the low-water flow rate using a finite-difference grid prepared for the calculation of the flood flow rate $\mathrm{Q}=500 \mathrm{~m} 3 / \mathrm{s}$. Qq=100 m3/s, $\mathrm{n}=0.021$ is taken in the KMC.

Taking into account the need to solve the most difficult problem, namely, to ensure a stable water intake during the low-water period, studies of the flow fields in the immediate vicinity of the head of the water intake were carried out.

It turned out that when the width of the riverbed is reduced by half-dams (spurs), the width of the part of the stream that enters the water intake of the KMC becomes smaller. In this case, the flow depth and flow rate increase, which, apparently, should favorably affect the reliability of the water intake of the KMC (Fig. 4). 


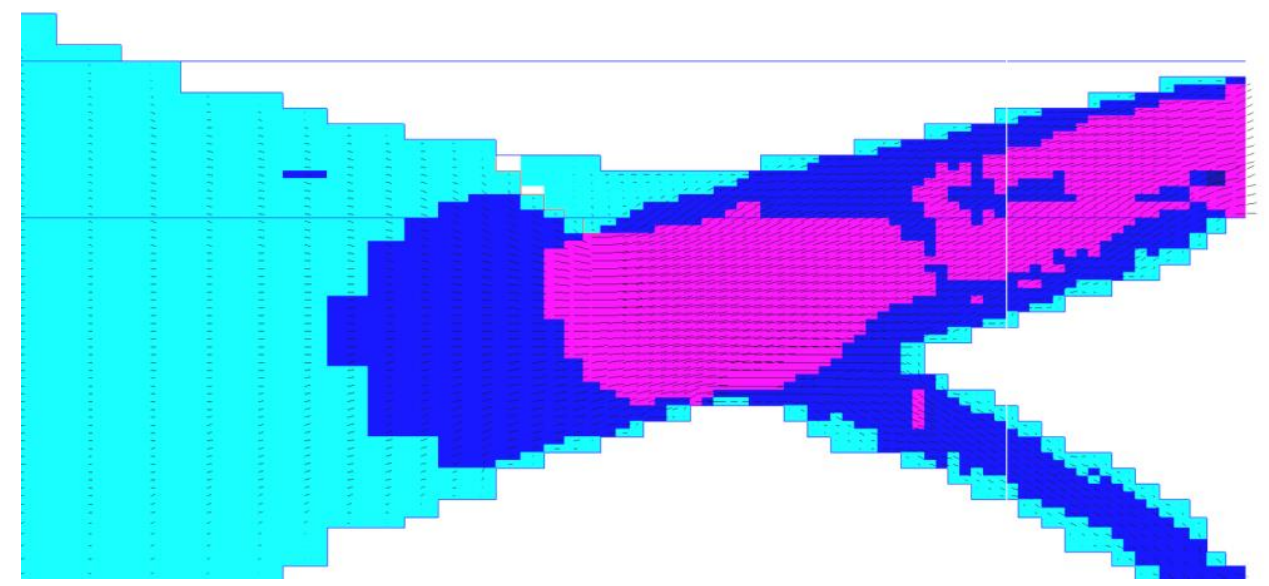

Fig. 4. Numerical experiment with the passage of the interline flow rate $Q=500 \mathrm{~m} 3 / \mathrm{s}$ in the region with a short jet-guiding spur № 2 on an enlarged scale. $Q_{c}=100 \mathrm{~m} 3 / \mathrm{s}, n=0.021$ is taken in the KMC.

Table the results of the numerical experiments carried out to study the effect of spurs on the flow width at a water flow rate in the Amu Darya river of $500 \mathrm{~m} 3 / \mathrm{s}$ and a flow rate of 100 $\mathrm{m} 3 / \mathrm{s}$ in the $\mathrm{KMC}$ are presented.

Table 1. Calculation options

\begin{tabular}{|c|l|c|}
\hline № & \multicolumn{1}{|c|}{ Option } & $\begin{array}{c}\text { The width of the stream taken into the water } \\
\text { intake of the KMC, } \mathrm{m}\end{array}$ \\
\hline 1 & Dam № 1, 50 m the length & 28.6 \\
\hline 2 & Dam № 1, 70 m the length & 24.3 \\
\hline 3 & Dam № 2, 65 m the length & 32.9 \\
\hline 4 & Dam № 2,120 m the length & 28.9 \\
\hline
\end{tabular}

Thus, judging by the data in Table 1, the device of a jet-guiding dam $150 \mathrm{~m}$ above the water intake gate in the CMC is more effective than when the dam is located $250 \mathrm{~m}$ above. In essence, dam № 2 with a length of $65 \mathrm{~m}$ does not affect the conditions at the water intake in the KMC at all, and dam № 2 with a length of $120 \mathrm{~m}$ is almost equivalent in its impact on the flow to dam № 1 with a length of $50 \mathrm{~m}$.

4 calculations were carried out with a continuous impenetrable dam installed $140 \mathrm{~m}$ upstream from the head of the water intake at a water flow rate of $300 \mathrm{~m} 3 / \mathrm{s}$ in the Amudarya River and a water flow rate of $30 \mathrm{~m} 3 / \mathrm{s}$ in the channel:

1. The length of the dam is $90 \mathrm{~m}$ ( 80 of them are in water).

2. The dam is extended by $10 \mathrm{~m}$ towards the right bank of the Amudarya River in comparison with option 1 .

3. The dam is extended by $20 \mathrm{~m}$ in comparison with option 1 .

4. The dam is extended by $30 \mathrm{~m}$ compared to option 1 (Fig. 5). 




Fig. 5. Results of the calculation of option 4

The results of calculations for options 1-4 are shown in Fig. 6.

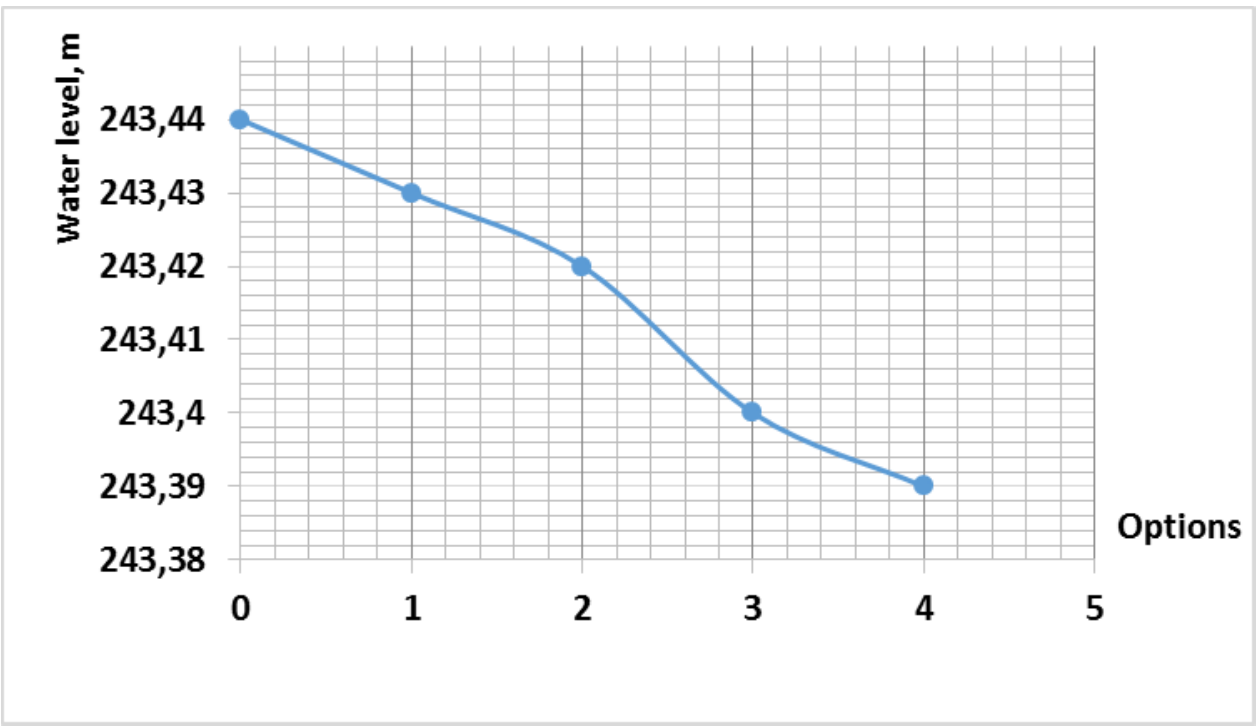

Fig. 6. Results of calculations for options 1-4

10 calculations were carried out with a solid impenetrable dam installed opposite the water intake:

1. The original dam is $80 \mathrm{~m}$ long (of which 20 are in water)

2. 10 The dam was extended each time by $10 \mathrm{~m}$ towards the right bank of the Amudarya River in comparison with the previous version.

The results of the calculation of option 10 are shown in Figure 7. 


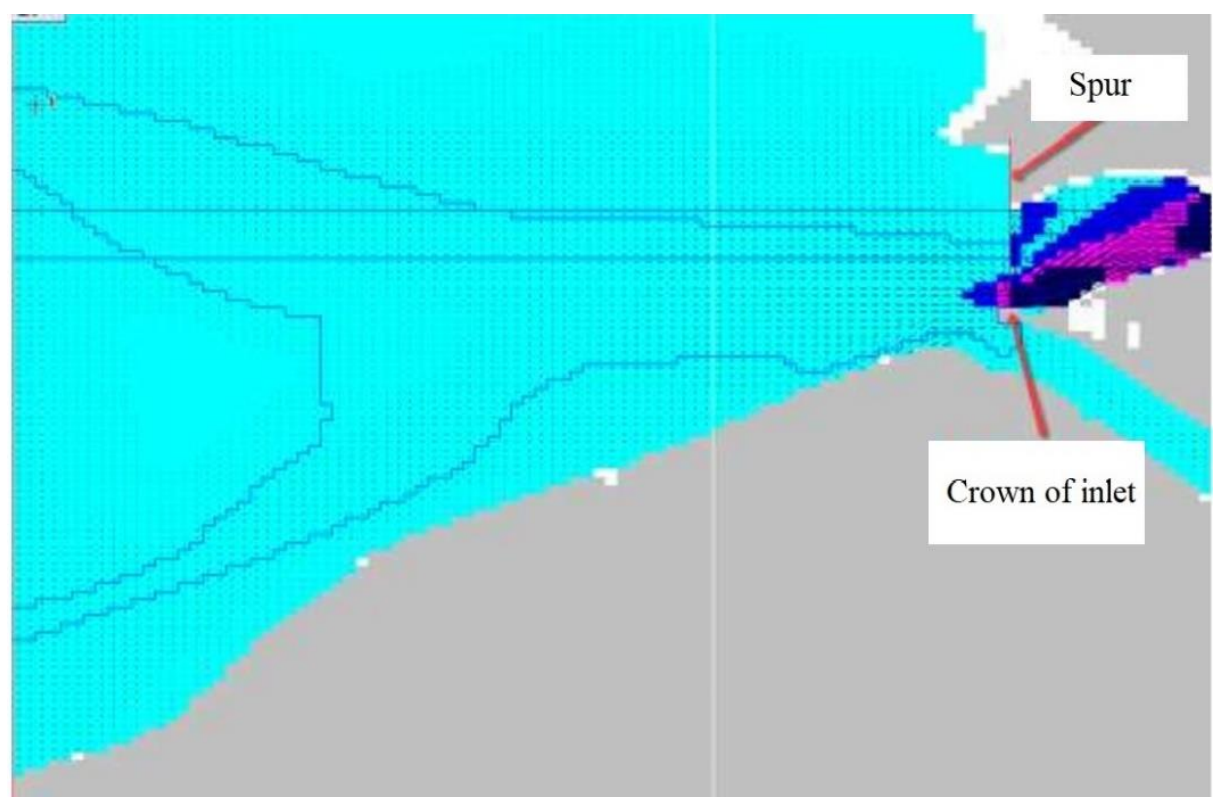

Fig. 7. Results of the calculation of option 10

The results of calculations for options 1-10 are shown in Fig. 8.

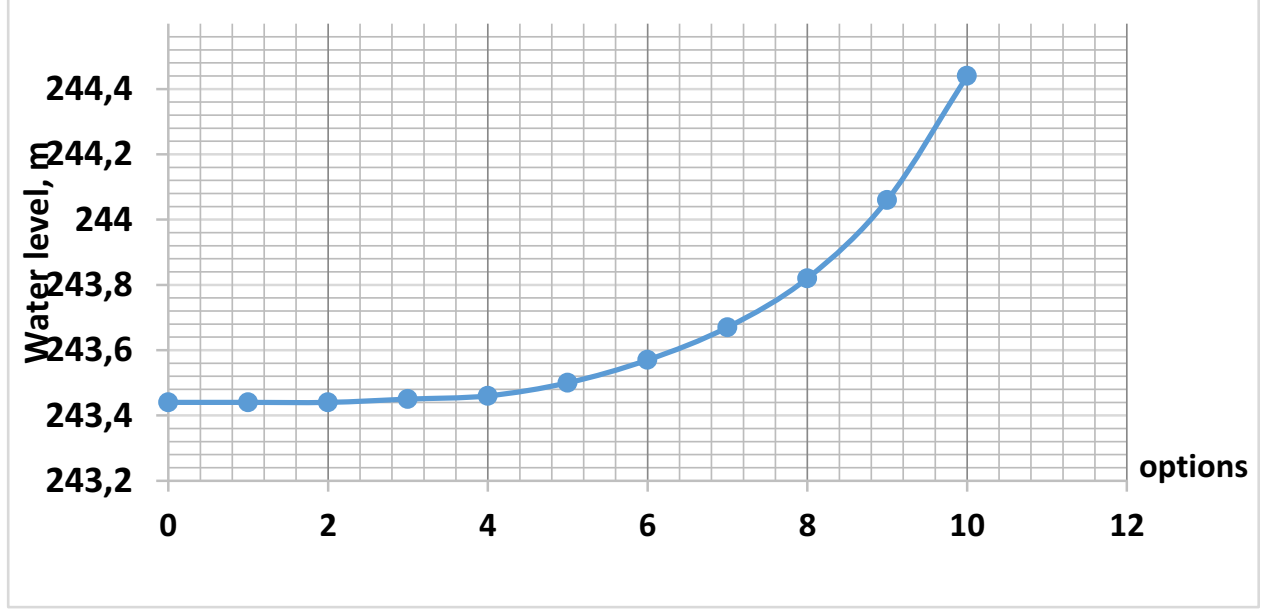

Fig. 8. Water level at the water intake

In addition, several options were investigated with the installation of a threshold in the head of the water intake and extension of the threshold into the river bed Amu Darya. In total, 5 variants were studied, in which the mark of the threshold and the ridge of the rapids extended into the channel remained constant, but only the length of the rapids in the channel changed from 10 to $42 \mathrm{~m}$ and one option with a threshold mark $0.5 \mathrm{~m}$ higher than the previous options and a spur length of $42 \mathrm{~m}$ :

1. Spur with a ridge mark equal to the threshold mark, $15 \mathrm{~m}$ wide, $10 \mathrm{~m}$ long perpendicular to the Amudarya river.

2. Spur with a crest mark of $243 \mathrm{~m}, 15 \mathrm{~m}$ wide, $20 \mathrm{~m}$ long perpendicular to the river Amu Darya. 
3. A spur with a ridge mark equal to the threshold, $15 \mathrm{~m}$ wide, $25 \mathrm{~m}$ long, which is the diagonal of a rectangle ( $20 \mathrm{~m}$ perpendicular to the Amudarya river and $15 \mathrm{~m}$ towards the river).

4. A spur with a ridge mark equal to the threshold, $15 \mathrm{~m}$ wide, $39 \mathrm{~m}$ long, which is the diagonal of a rectangle $(30 \mathrm{~m}$ perpendicular to the Amudarya river and $15 \mathrm{~m}$ opposite the river).

5. Spur with a ridge mark equal to the threshold, $15 \mathrm{~m}$ wide, $42 \mathrm{~m}$ long, which is the diagonal of a rectangle $(30 \mathrm{~m}$ perpendicular to the Amudarya river and $30 \mathrm{~m}$ opposite the river).

6. Spur with a ridge mark $0.5 \mathrm{~m}$ above the threshold, $15 \mathrm{~m}$ wide, $42 \mathrm{~m}$ long, which is the diagonal of a rectangle $(30 \mathrm{~m}$ perpendicular to the Amudarya river and $30 \mathrm{~m}$ towards the river).

In Fig. 9 shows the results of calculating the plan of currents in the area of the water intake during the construction of a sill and a flooded stream-guide spur.

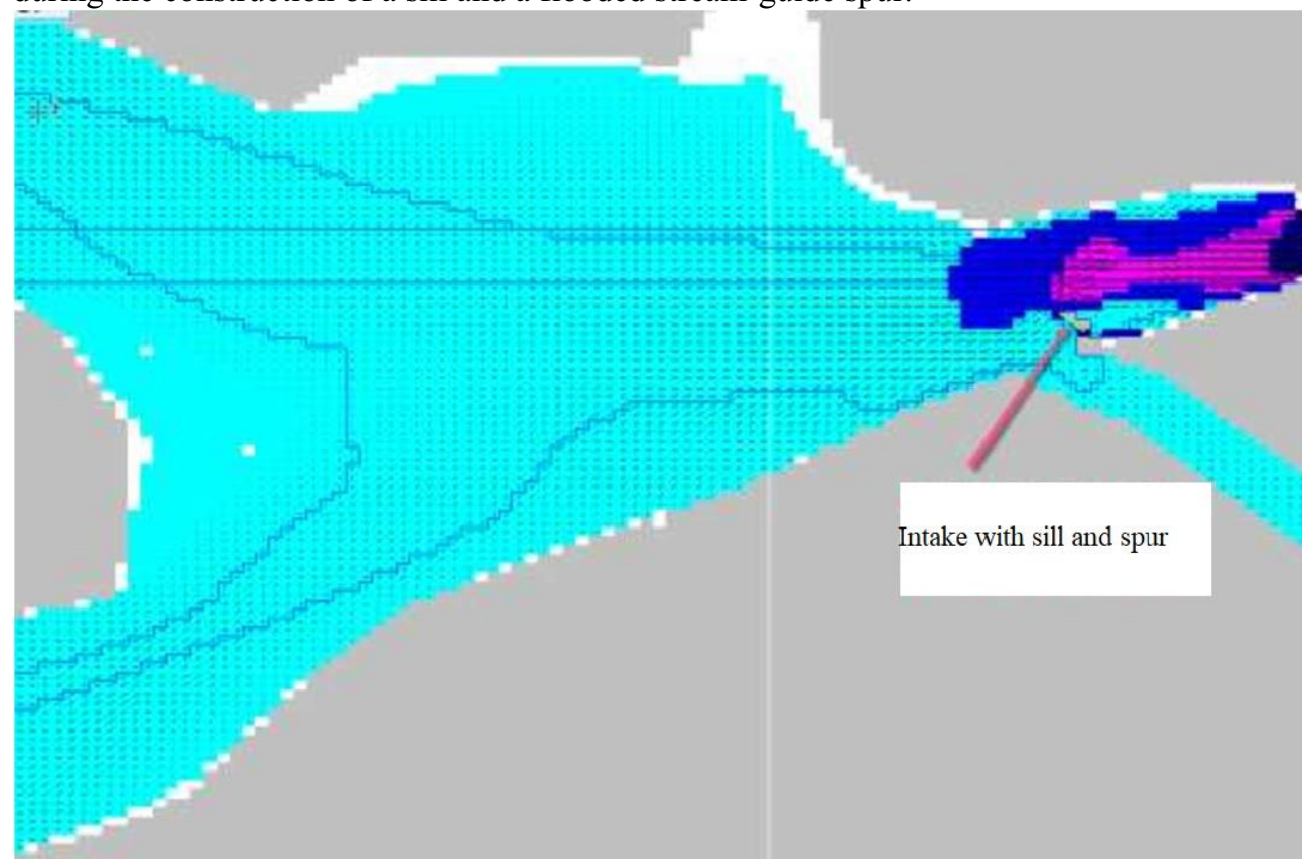

Fig. 9. The plan of the currents in the area of the water intake during the construction of the sill and the flooded stream-guide spur

The calculation results for options $1-6$ are shown in Fig. 9. 


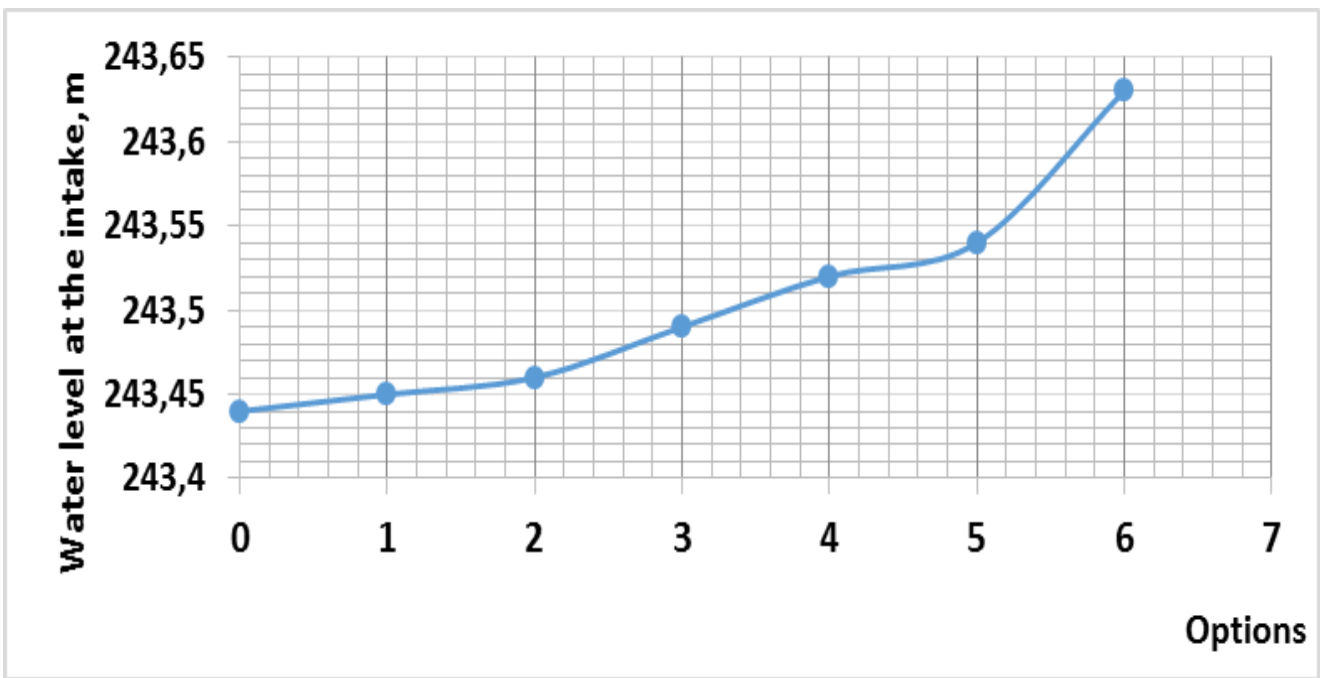

Fig. 10. Water level at the water intake

Analysis of the results shows that the placement of an additional threshold in the river bed. The Amudarya improves the situation by increasing the water level at the water intake. The threshold is flooded even at low water levels, which reduces the speed load on its body. At the same time, the sill located directly at the beginning of the canal partially protects the water intake from the influx of sediments, and rather high velocities of water overflowing the sill in the channel ensure the transit of sediments, which can reduce their ingress into the water intake. Such measures will reduce the turbidity of the water entering the canal. This, in turn, reduces the intensity of the process of siltation of the supply channel of the pumping station.

\section{Conclusions}

Thus, the results of the analysis of the above studies, the authors make it possible to draw a conclusion about the applicability of a numerical model composed of the equations of shallow water - the vector equation of conservation of momentum and the scalar equation of conservation of mass, when describing a flow with the presence of circulation zones, which is typical when the water flow is constrained by blind dams. In this case, the solution pulsates around a certain average value, and the average length of the circulation zone behind the sudden expansion of the open flow is in good agreement with laboratory experiments.

Numerical studies have shown that the construction of a jet-directing dam $150 \mathrm{~m}$ above the water intake at the $\mathrm{KMC}$ is more effective than when the dam is located $250 \mathrm{~m}$ higher. In fact, dam №2 with a length of $65 \mathrm{~m}$ does not affect the conditions at the water intake at the KMC at all, and dam №2 with a length of $120 \mathrm{~m}$ is almost equivalent in its impact on the flow to dam №1 with a length of $50 \mathrm{~m}$.

Analysis of the results shows that the placement of an additional threshold in the river bed. The Amudarya improves the situation by increasing the water level at the water intake. The threshold is flooded even at low water levels, which reduces the speed load on its body. At the same time, the sill located directly at the beginning of the canal partially protects the water intake from the influx of sediments, and rather high velocities of water overflowing the sill in the channel ensure the transit of sediments, which can reduce their ingress into the water intake. Such measures will reduce the turbidity of the water entering the canal. 
This, in turn, reduces the intensity of the process of siltation of the supply channel of the pumping station.

\section{References}

1. Bazarov, D., Markova, I., Norkulov, B., Isabaev, K., Sapaeva, M. Operational efficiency of water damless intake. IOP Conference Series: Materials Science and Engineering. 2020. 869(7). DOI:10.1088/1757-899X/869/7/072051.

2. Bazarov, D., Markova, I., Raimova, I., Sultanov, S. Water flow motion in the vehicle of main channels. IOP Conference Series: Materials Science and Engineering. 2020. 883. Pp. 012001. DOI:10.1088/1757-899x/883/1/012001.

3. Bazarov, D., Uralov, B., Matyakubov, B., Vokhidov, O. The effects of morphometric elements of the channel on hydraulic resistance of machine channels of pumping stations. Mater. Sci. Eng. 2020. 869(072014). DOI:10.1088/1757-899X/869/7/072015.

4. Krutov, A., Bazarov, D., Norkulov, B., Obidov, B., Nazarov, B. Experience of employment of computational models for water quality modelling. E3S Web of Conferences. 2019. 97. DOI:10.1051/e3sconf/20199705030.

5. Krutov, A., Norkulov, B., Artikbekova, F., Nurmatov, P. Optimal location of an intake at a reservoir prone to salt diffusion. IOP Conference Series: Materials Science and Engineering. 2020. 869. Pp. 072020. DOI:10.1088/1757-899x/869/7/072020.

6. Bazarov, D., Shaazizov, F., Erjigitov, S. Transfer of Amudarya flowing part to increase the supportability of the Uzbekistan southern regions. IOP Conference Series: Materials Science and Engineering. 2020. 883. Pp. 012068. DOI:10.1088/1757899x/883/1/012068.

7. Bazarov, D., Uralov, B., Matyakubov, B., Vokhidov, O., Uljaev, F., Akhmadi, M. The effects of morphometric elements of the channel on hydraulic resistance of machine channels of pumping stations. IOP Conference Series: Materials Science and Engineering. 2020. 869(7). DOI:10.1088/1757-899X/869/7/072015.

8. Uralov, B., Xidirov, S., Matyakubov, B. River channel deformations in the area of damless water intake River. Mater. Sci. Eng. 2020. 869(072015). DOI:10.1088/1757899X/869/7/072014.

9. Bazarov, D., Norkulov, B., Vokhidov, O., Uljaev, F., Ishankulov, Z. Two-dimensional flow movement in the area of protective regulatory structures. IOP Conference Series: Materials Science and Engineering. 2020. 890(1). DOI:10.1088/1757899X/890/1/012162.

10. Obidov, B., Choriev, R., Vokhidov, O., Rajabov, M. Experimental studies of horizontal flow effects in the presence of cavitation on erosion - free dampers. IOP Conference Series: Materials Science and Engineering. 2020. 883. Pp. 012051. DOI:10.1088/1757899x/883/1/012051.

11. Rakhmatov, N., Maksudova, L., Jamolov, F., Ashirov, B., Tajieva, D. The concept of creating a new water management system in the region. IOP Conference Series: Materials Science and Engineering. 2020. 883. Pp. 012007. DOI:10.1088/1757899x/883/1/012007.

12. Obidov, B., Vokhidov, O., Shodiev, B., Ashirov, B., Sapaeva, M. Hydrodynamic loads on a water drain with cavitation quenchers. IOP Conference Series: Materials Science and Engineering. 2020. 883. Pp. 012011. DOI:10.1088/1757-899x/883/1/012011.

13. Bazarov D.R. Scientific substantiation of new numerical methods for calculating the deformation of riverbeds composed of easily eroded soils. Moscow, 2000.

14. Artikbekova, F.K. ESTIMATING THE PROCESSES IN INLET CANAL WITH THE CONSIDERATION OF THE OPERATIONAL FEATURES OF PUMP STATIONS. Tashkent, 2020. ISBN:9781479978007. 
15. Atykbekova, F., Uljaev, F., Jumaboeva, G., Gayur, A., Ishankulov, Z., Jumanov, O. Operation damless intake of the Amudarya river (Central Asia). IOP Conference Series: Materials Science and Engineering. 2020. 883(1). DOI:10.1088/1757899X/883/1/012003.

16. Krutov, A., Norkulov, B., Artikbekova, F., Nurmatov, P. Optimal location of an intake at a reservoir prone to salt diffusion. IOP Conference Series: Materials Science and Engineering. 2020. 869(7). DOI:10.1088/1757-899X/869/7/072020.

17. A.K., K. Sovershenstvovaniye konstruktsiy besplotinnykh vodozabornykh gidrouzlov $s$ donnymi tsirkulyatsionnymi porogami na malykh gornykh rekakh. Publishing House of the Academy of Sciences of the USSR, Moscow, 2015. $155 \mathrm{p}$.

18. Artykbayeva F., Nishanbayev KH., Sharipov O. O., Azimov S. S., U.S.M. Zatrudneniya ekspluatatsii besplotinnogo vodozabora reki amudar'ya v karshinskiy magistral'nyy kanal. Web of Scholar. 2019. 2(6(24)). Pp. 13-15. DOI:DOI: https://doi.org/10.31435/rsglobal_wos/12062018/5745. URL: https://wsconference.com/webofscholar.

19 Mukhamedov Y.S., M.O.Y. Ruslo- i nanosoreguliruyushchiye meropriyatiya pri vodozabore iz reki Amudar'i v magistral'nyye kanaly (KMC). Materialy Resp. nauchno-praktich.konf. «Problemy i zadachi tselevogo i effektivnogo ispol'zovaniya vodnykh resursov fermerskimi khozyaystvami». 2009. Pp. 147-150.

20. Mukhamedov Y.S, M.O.Y. Bor'ba s nanosami pri vodozabore iz reki Amudar'i (na primere Kashinskogo magistral'nogo kanala). Materialy Respublikanskoy nauchnoprakticheskoy konferentsii «Problemy i zadachi tselevogo i effektivnogo ispol'zovaniya vodnykh resursov fermerskimi khozyaystvami». 2009. Pp. 150-153. 